\author{
Nikolaos E. Karkalos, Angelos P. Markopoulos Athens, Greece, \\ Tamás Makkai, János Kundrák, Miskolc, Hungary
}

\title{
INFLUENCE OF DEPTH OF CUT AND CUTTING SPEED ON CUTTING FORCES IN FACE MILLING UNDER CONSTANT CHIP CROSS-SECTION CONDITIONS
}

\begin{abstract}
In various high-end industries such as the automotive and the aerospace industry, face milling is one of the most preferred solutions for the fabrication of flat surfaces with high quality. During machining it is desired to achieve the required result with high efficiency. However, attention should be paid so that forces are kept within acceptable limits for maintaining energy consumption and loading of machine tool at relatively low levels. Thus, it is important to determine the influence of process conditions, such as depth of cut or cutting speed, on cutting forces. In this study, this is attempted by conducting experiments at two different depths of cut and four different cutting speeds for cases with the same chip cross-section value. After analysis of obtained results, useful conclusions on the influence of these parameters on cutting forces are presented.
\end{abstract}

Keywords: face milling; cutting forces; specific cutting forces; chip cross-section.

\section{INTRODUCTION}

Face milling process has long been considered appropriate for the efficient manufacturing of prismatic surfaces of a large variety of components in industrial practice. The expected goals of the manufacturing process are not only the rendering of the appropriate geometric shapes and dimensions but also surface integrity of the workpiece as well as high productivity must be ensured. By controlling the cutting forces occurring due to tool-workpiece interaction during milling, it is possible to achieve lower damage of the workpiece, lower energy consumption of the machine tool and prolong cutting tool life. Efficient control of cutting forces can be managed by selecting the appropriate process parameters values. Previous research [1-3] has demonstrated that it is possible by varying feed rate values. Thus, in the present study, the effect of varying depth of cut and cutting speed values will be analyzed.

The correlation of depth of cut and cutting speed with cutting forces during milling as well as their relative impact on them has already being a topic of interest in the relevant literature. It was shown that, by increasing cutting speed, it is possible to obtain lower cutting forces and particularly, the $\mathrm{x}$ and $\mathrm{y}$ component of cutting forces are more significantly influenced from this change. This effect is existent also when milling at very high speeds, namely during High Speed Milling (HSM) and does not differ a lot in up and down milling [4]. The trend of cutting force decrease is described mostly as linear [5] but it was sometimes reported that the decrease can have a non-constant rate [6]. 
Although the effect of cutting speed on cutting forces is generally acknowledged, its relative importance compared to that of other process parameters is not always certain; thus, it is usually stated that it has a lower significance regarding cutting forces $[6,7]$, but in some cases the opposite is stated [8]. The explanation on the influence of cutting speed on cutting forces can be related to the fact that increased temperatures due to higher cutting speed result in softening of workpiece material [4].

By increasing the depth of cut, it is inevitable that all cutting force components will increase, with the most significantly affected force components being $F_{x}$ and $F_{y}$. The variation of depth of cut is shown to have a significant effect on cutting forces [7] and the increase of cutting forces with increased depth of cut can be non-linear, mostly at higher values $[5,9]$. The reason for the increase of cutting forces with the increase of depth of cut is considered to be the increase of tool-workpiece contact length and subsequently the increased cross-sectional area of the uncut chip which is removed $[4,10]$.

\section{EXPERIMENTAL CONDITIONS}

In the present work, face milling experiments are carried out under various process conditions on $\mathrm{C} 45$ carbon steel workpieces with a hardness value of HB180. The experiments are conducted with a milling head with a single cutting insert mounted on it. The aim of the present research is the determination of the influence of depth of cut and cutting speed on cutting forces and specific cutting forces during face milling. Additionally, their relative importance in cases where the chip cross-sectional area, denoted as $A_{c}$, is constant whereas depth of cut and feed rate values are chosen so that $\mathrm{A}_{\mathrm{c}}$ remains constant.

The experiments are with a constant $\mathrm{A}_{\mathrm{c}}$ value of $0.32 \mathrm{~mm}^{2}$, two different depths of cut, namely $0.4 \mathrm{~mm}$ and $0.8 \mathrm{~mm}$, two different feed rate values, namely $0.4 \mathrm{~mm} /$ tooth and $0.8 \mathrm{~mm} /$ tooth and four different cutting speed values in the range of 100 to $400 \mathrm{~m} / \mathrm{min}$. All the experiments are performed under dry machining conditions and during the experiments, components of force, namely $F_{x}, F_{y}, F_{z}$ are measured in a coordinate system relative to the workpiece by a Kistler 9257A dynamometer. The measured signal is then amplified using three Kistler 5011A charge amplifiers. Finally the data are transferred to a PC using a Compact DAQ9171 data collector by National Instruments Company. The recording of force data is conducted using software prepared in the LabView programming language. Other experimental conditions include:

- Machine Tool: PerfectJet MCV-M8 vertical machining centre.

- Cutting insert: Sandvik R215.44-15T308M-WL GC4030 coated carbide insert $\left(\kappa_{\mathrm{r}}=90^{\circ} ; \gamma_{\mathrm{o}}=0^{\circ} ; \alpha_{\mathrm{o}}=11^{\circ} ; \mathrm{r}_{\varepsilon}=0.8 \mathrm{~mm}\right)$. 
- Milling head type: Sandvik R252.44-080027-15M face milling head $\left(\mathrm{D}_{\mathrm{s}}=80\right.$ $\mathrm{mm})$.

- Workpiece dimensions: $58 \mathrm{~mm}$ width, $50 \mathrm{~mm}$ length

\section{EXPERIMENTAL RESULTS AND DISCUSSION}

After the experimental work is completed, diagrams for each cutting force component are recorded and then appropriately processed in order to determine the maximum cutting force values for each force component during face milling. The maximum values for $F_{x}, F_{y}$ and $F_{z}$ are plotted in Figure 1, in respect to cutting speed and depth of cut values.

It can be seen from the results depicted in Figure 1 that the increase of cutting speed values results in a clear decrease of $F_{x}$ and $F_{y}$ cutting force components in the majority of cases, whereas the increase of depth of cut is leading to an increase of cutting forces. These results are in accordance with the ones observed in other experimental works in the relevant literature [4, 5, 9-11]. From all cases, it can be seen that the $y$-component of cutting forces exhibits the largest values compared to the other two force components. However, $F_{z}$ values do not exhibit the same trends and particularly a slight decrease of $F_{z}$ value was observed with higher depth of cut.

In order to investigate the effect of depth of cut and cutting speed on the cutting force components, it is required to compute the variation of cutting forces in respect to the variation of depth of cut or cutting speed values. The ratio of change of forces between cases with different depth of cut values can be computed as follows: ratio of change $=\left|\mathrm{F}_{\mathrm{ap}=0.8} / \mathrm{F}_{\mathrm{ap}=0.4}\right|$. From the diagrams plotted in Figure 1, it can be observed that the difference between forces values at $\mathrm{a}_{\mathrm{p}}=0.4 \mathrm{~mm}$ and $a_{p}=0.8 \mathrm{~mm}$ is clearly increased in the case of $F_{x}$ and $F_{y}$ components of cutting forces. In the case of $F_{z}$ the trend is similar with the trend observed for the other two cutting forces components but as the ratio values are below 1 , it indicates that, actually, the difference between the force values at $a_{p}=0.4 \mathrm{~mm}$ and $a_{p}=0.8 \mathrm{~mm}$ is decreasing as the ratio approaches the value 1.0. The difference between force values at the two different depths of cut is more evident in the case of $F_{x}$ component, as the increase is almost 1.3 times, whereas for $F_{y}$ it is 1.1 times and for $F_{z}$ it is almost 0.95 times, meaning that $F_{z}$ actually is almost constant with increasing depth of cut. These trends can be also deduced from the difference observed in the slopes of the regression trend lines in each case. If the same calculation of ratio of change of cutting forces is conducted between cases with cutting speed values of $100 \mathrm{~m} / \mathrm{min}$ and $400 \mathrm{~m} / \mathrm{min}$, the influence of cutting speed on cutting forces can be determined. The calculations can be conducted on both cases with $a_{p}=0.4 \mathrm{~mm}$ and $a_{p}=0.8 \mathrm{~mm}$. For the $F_{x}$ component, the force value is 1.41 times higher at $100 \mathrm{~m} / \mathrm{min}$ than at $400 \mathrm{~m} / \mathrm{min}$ for $a_{p}=0.4 \mathrm{~mm}$, whereas for $a_{p}=0.8 \mathrm{~mm}$ it is 1.31 times higher. In the case of $F_{y}$ component, this increase is 1.08 
times in the case of $a_{p}=0.4 \mathrm{~mm}$ and 1.06 times in the case of $a_{p}=0.8 \mathrm{~mm}$. Finally, for $\mathrm{F}_{\mathrm{z}}$ component the increase is 1.16 times in the case of $\mathrm{a}_{\mathrm{p}}=0.4 \mathrm{~mm}$ and 0.99 times in the case of $a_{p}=0.8 \mathrm{~mm}$. Thus, it is clear that the variation of cutting speed affects $F_{x}$ more significantly than the other two components of force and also the ratio of change is larger at lower depth of cut value.
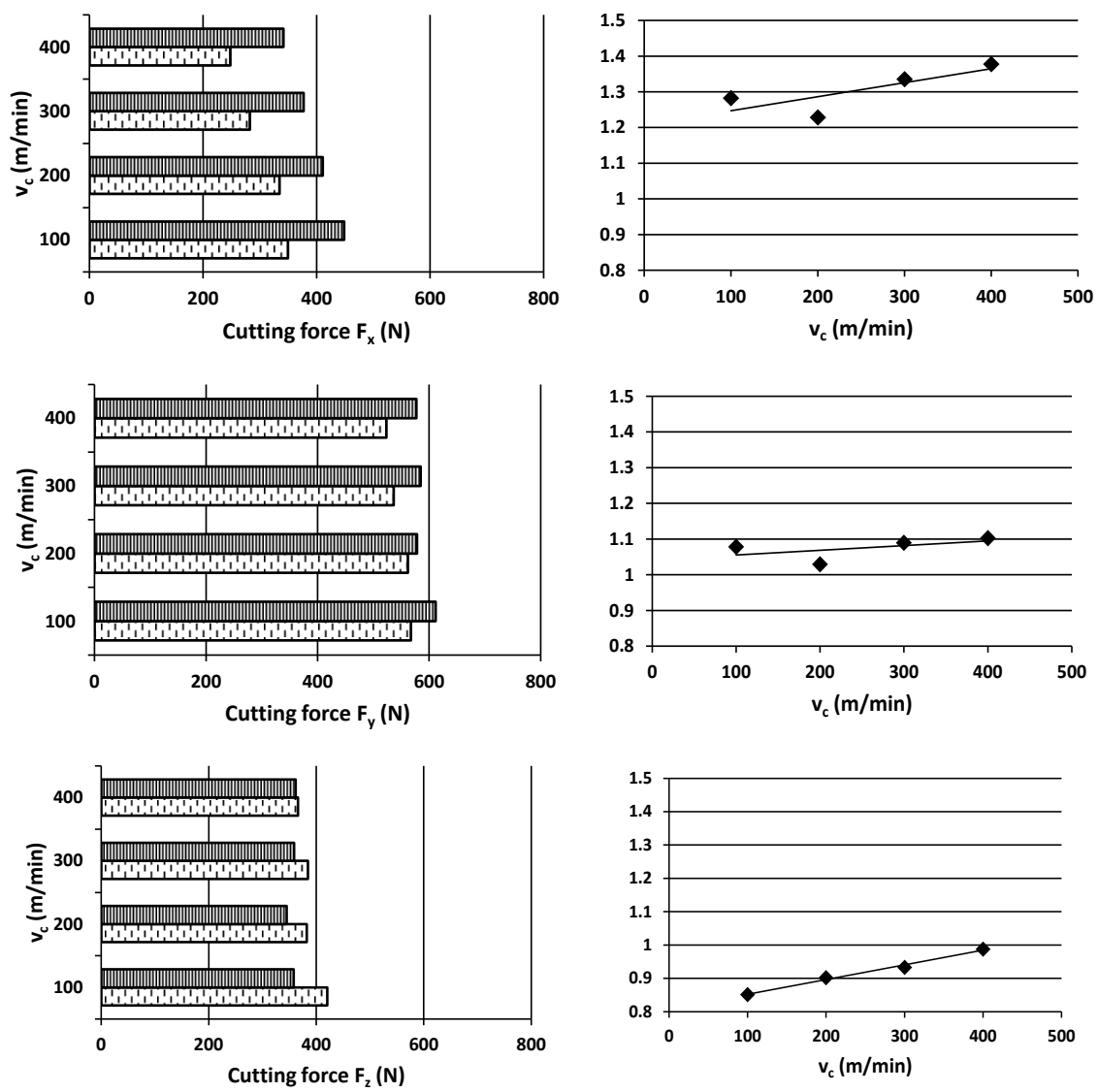

四 ap $=0.8 \mathrm{~mm}$ 닌 ap $=0.4 \mathrm{~mm}$

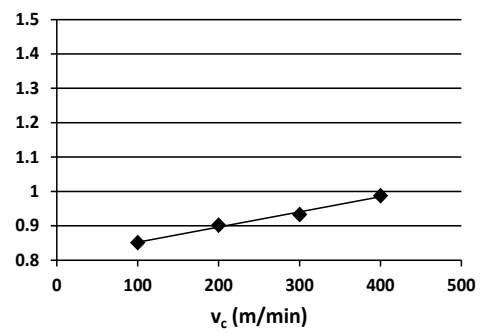

- ratio of change - trendline

Figure 1 - Cutting forces for two different depths of cut and four different cutting speeds (left column) and ratio of change of forces between different depths of cut for various cutting speeds (right column) 
Furthermore, it can be revealed that the effect of depth of cut is more significant than the effect of cutting forces as a 4-fold variation of cutting speed has almost the same effect as a 2-fold variation of depth of cut.

In Figure 2, the results regarding the specific cutting forces are presented. The specific cutting forces are calculated as the ratio of cutting forces components to the chip cross-section value. In the present case, the variation of specific cutting forces in respect to variations of depth of cut and cutting speed is similar to the one observed in the case of cutting forces, as $A_{c}$ value is the same in all cases.
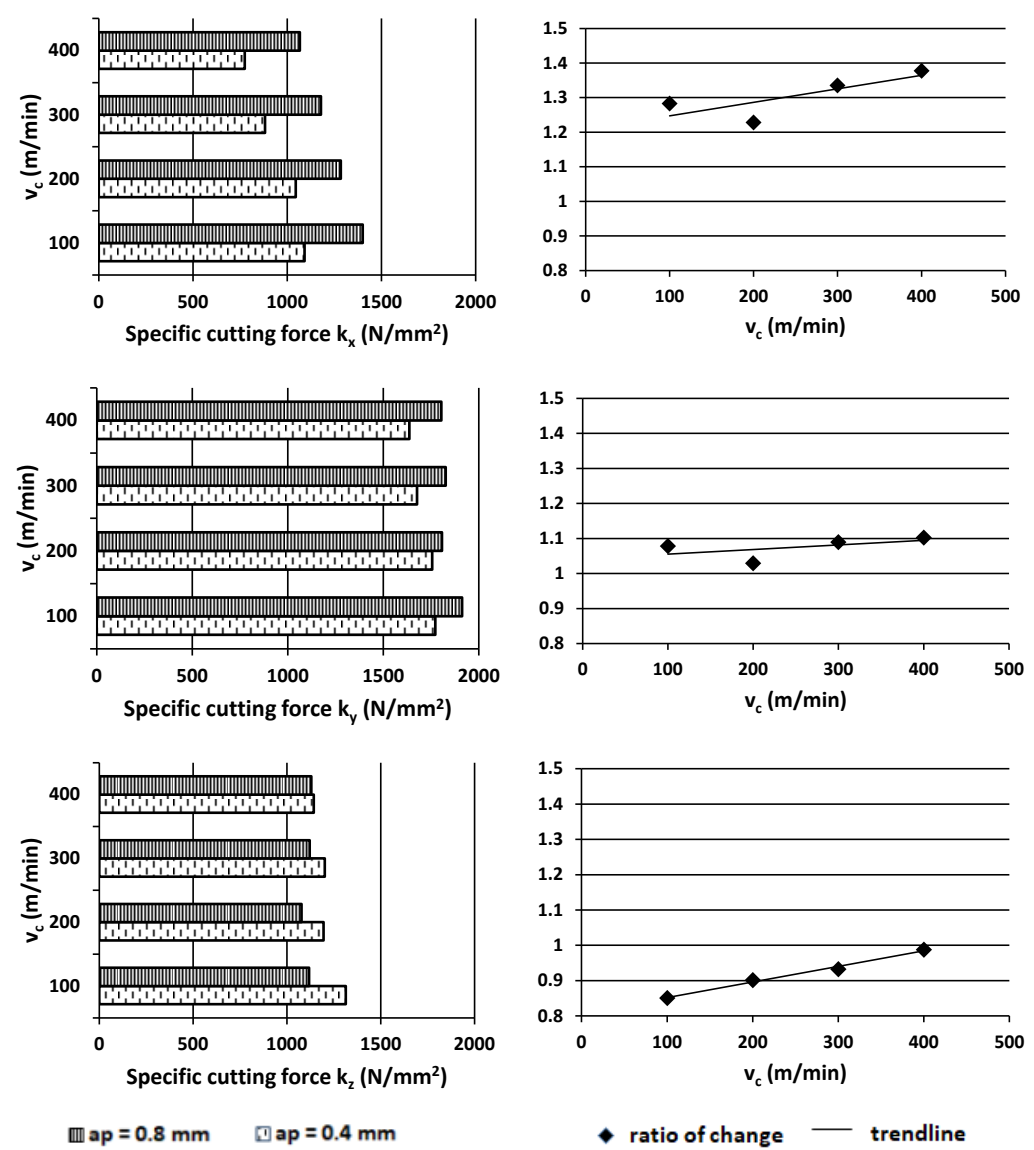

Figure 2 - Specific cutting forces for two different depths of cut and four different cutting speeds (left column) and ratio of change of specific forces between different depths of cut for various cutting speeds (right column) 


\section{SUMMARY}

At the reported experiments it was confirmed that by maintaining the value of $\mathrm{A}_{\mathrm{c}}$ constant, increasing feed, i.e. $\mathrm{a}_{\mathrm{p}} / \mathrm{f}_{\mathrm{p}}$ ratio decreased, the cutting force decreases and so does the taken up performance. In this paper the increase of depth of cut, with $\mathrm{A}_{\mathrm{c}}$ constant, i.e. an increase of $\mathrm{a}_{\mathrm{p}} / \mathrm{f}_{\mathrm{p}}$ ratio, an increasing effect on the change of the cutting force is observed. The increase of $a_{p}$ increases $F_{x}$ component, while the value of $F_{y}$ increases slightly. However, the value of $F_{z}$ decreases slightly. This characteristic is similar at each cutting speed in the examined range. The ratio of change showed that the change is small, therefore, the change of depth of cut does not limit the choice of cutting data, namely the Technological Plan.

\section{ACKNOWLEDGEMENTS}

The authors greatly appreciate the support of the National Research, Development and Innovation Office - NKFIH (No. of Agreement: K 116876).

The described study was carried out as part of the EFOP-3.6.1-16-00011 "Younger and Renewing University - Innovative Knowledge City - institutional development of the University of Miskolc aiming at intelligent specialization" project implemented in the framework of the Szechenyi 2020 program. Both supports are gratefully acknowledged.

References: 1. Kundrák, J., Makkai, T., Markopoulos, A.P.: Investigating the impact of feed and cutting speed on cutting forces for the increase of surface removal rate in face milling, Cutting $\&$ Tools in Technological Systems: NTU 'KhPI’ 87, pp.126-132. 2. Kundrák, J., Makkai, T., Deszpoth, I., Nagy, A.: Investigation of cutting force in face milling, Cutting \& Tools in Technological Systems: NTU 'KhPI' 87, pp.118-125. (2017). 3. Kundrák, J., Markopoulos, A.P., Makkai, T., Deszpoth, I., Nagy, A.: Analysis of the effect of feed on chip size ratio and cutting forces in face milling for various cutting speeds, Manufacturing Technology 18(3), pp. 431-438. (2018). 4. Čekić, A., Begić-Hajdarević, Đ., Kulenović, M.: Effect of the cutting parameters on cutting forces in high speed face milling, Tehnički Vjesnik 20(5), pp.775-780. (2013). 5. Subramanian, A.V.M., Nachimuthu, M.D.G, Cinnasamy, V.: Assessment of cutting force and surface roughness in $\mathrm{LM}_{6} / \mathrm{SiC}_{\mathrm{p}}$ using response surface methodology, Journal of Applied Research and Technology 15, pp. 283-296. (2017). 6. Kaya, E., Akyüz, B.: Effects of cutting parameters on machinability characteristics of Ni-based superalloys: a review, Open Engineering 7, pp. 330-342. (2017). 7. Ghani, J.A., Choudhury, I.A., Hasan, H.H.: Application of Taguchi method in the optimization of end milling parameters, Journal of Materials Processing Technology 145, pp. 84-92. (2004). 8. Malghan, R.L., Rao, M.C.K., Arun Kumar, S., Rao, S.S., D'Souza, $J .:$ Effect of process parameters in face milling operation and analysis of cutting force using indirect method, Materials and Manufacturing Processes 33(13), pp. 1406-1414. (2018). 9. Kilickap, E., Yardimeden, A., Çelik, Y.H.: Mathematical modelling and optimization of cutting force, tool wear and surface roughness by using artificial neural network and response surface methodology in milling of Ti6242S, Applied Sciences 7, 1064. (2017). 10. Subramanian, M., Sakthivel, M., Sooryprakash, K., Sudharakan, R.: Optimization of cutting parameters for cutting force in shoulder milling of A17075-T6 
using response surface methodology and genetic algorithm, Procedia Engineering 64, pp. 690-700. (2013). 11. Yalcin, U., Karaoglan, A.D., Korkut, I.: Optimization of cutting parameters in face milling with neural networks and Taguchi based on cutting force, surface roughness and temperatures, International Journal of Production Research 51(11), pp. 3404-3414. (2013).

\title{
Ніколаос Е. Каркалос, Ангелос Р. Маркопулос, Афіни, Греція, Тамаш Маккаі, Янош Кундрак, Мішкольц, Угорщина \\ ВПЛИВ ГЛИБИНИ І ШВИДКОСТІ РІЗАННЯ НА СИЛИ РІЗАННЯ ПРИ ТОРЦЕВОМУ ФРЕЗЕРУВАННІ 3 ПОСТІЙНИМ ПОПЕРЕЧНИМ ПЕРЕРІЗОМ ЗРІЗУ
}

\begin{abstract}
Анотація. У різних високотехнологічних галузях, таких як автомобільна $і$ аерокосмічна промисловість, ториеве фрезерування є одним з найбільш бажаних рішень для виготовлення плоских поверхонь з високою якістю. Під час обробки бажсано досягти необхідного результату $з$ високою ефективністю. Однак слід звернути увагу на те, щоб сили різання перебували в допустимих межах для підтримки енергоспоживання $i$ завантаження верстата на відносно низьких рівнях. Таким чином, важливо визначити вплив умов процесу, таких як глибина різання або швидкість різання, на сили різання. У иьому дослідженні це робиться шляхом проведення експериментів на двох різних глибинах різання і чотирьох різних швидкостях різання для випадків з однаковим значенням поперечного перерізу стружки. Після аналізу отриманих результатів представлені корисні висновки про вплив цих параметрів на сили різання. В експериментах було підтверджено, що при незмінності значення потужсності різання (Ас), подача зменшується, сила різання зменшується $i$, відповідно, знижується продуктивність. У иьому дослідженні спостерігається збільшення глибини різання з постійною Ас, тобто збільшення відношення ар / fp, ще збільшує вплив на зміну сили різання. Збільшення ар збільшує компонент Fx, тоді як значення Fу трохи збільшується. Однак значення Fz дещо зменшується. Ця характеристика однакова на кожній швидкості різання в досліджуваному діапазоні. Коефіцієнт зміни показав, щчо зміна параметру невелика, тому зміна глибини різання не обмежує вибір даних різання, а саме технологічного плану.
\end{abstract}

Ключові слова: торчеве фрезерувння; сили різання; специчфічні сили різання; поперечний переріз стружки. 